\title{
Quality Approach In The Development Of Management Information System In Higher Education
}

\author{
Fory Armin Naway, Arifin Suking, Ikhfan Haris dan Abdul Rahmat \\ Faculty of Education, Universitas Negeri Gorontalo \\ email: ikhfanharis@ung.ac.id danabdulrahmat@ung.ac.id
}

\begin{abstract}
Management Information Systems (MIS) is a data processing procedure based on the information technology as a tool to produce the information in a timely and effective way to support the management in decision making process. In developing a management information system, quality approach has become essential factor due to the function of quality control in assuring the performance of the organization activities. Establishing of Management Information Systems at the higher education institution driven by many reason, such as: (1) Management Information Systems is designed to support the operations, management, and decision functions of an organization, (2) Management Information Systems enable the organizations planning, control, and operational functions to be carried out effectively and the means of efficient coordination between Departments; quick and reliable referencing (3) Management Information System could be a tool by striving to highest quality standards in the teaching and learning process, (4) Management Information Systems provides a valuable time-saving benefit to the workforce in term of quick and reliable referencing; access to relevant data and documents; use of less labor; improvement in organizational and departmental techniques; management of day-to-day activities and (5) Management Information Systems can effectively respond to the changing of society demands in their interest in dependable and reliable information as well as easily accessible with interactively forms. This paper describes the quality approach in developing of Management Information system in Higher Education Institution, which highlighted the role Management Information Systems plays in the success of the operation and in allowing the higher education institution to evolve and meet the challenges posed by the government, students and other stakeholders.
\end{abstract}

Key words: quality, system, information, management, higher education.

\section{INTRODUCTION}

In the management of an institution of higher education, data and information are important assets both in academic and non-academic activities (George and King, 1991; Davy, 1998; Neyland and Surridge, 2002; Merzuki and Latif 2017). In addition, information is also a vital element in the determination of plans, strategies and management policies (Lederer and Sethi, 1991; Szopa and Jalocha, 2014). Therefore, required a reliable and reliable information management system. However, in fact, the optimal management of information, in terms of efficient and effective, is not an easy thing to achieve, because it involves, in general, a complex system, where the existing data 
sources vary widely, the scope of work involved is quite extensive, coupled with the lack of human resources able to master the technology used.

With the current communication and information technology, information management can be done more optimally with the help of computers, application programs, communication devices and internet/intranet network. The use of communication and information technology aims to achieve efficiency in various aspects of information management, which is shown by the speed and timeliness of processing, as well as the accuracy and correctness of information. This is needed in the administration and management of the organization, including in the management of academic activities. In addition to improving the efficiency and effectiveness of administration and management, can also improve the academic quality of an institution of higher education.

On the other hand, the rapid development of communication and information technology that occurs outside universities should be responded quickly. If not, then the consequences of college will be left behind. Recognizing all of the above, it is appropriate for universities to anticipate and determine the direction of policy or strategy of utilization of communication and information technology in supporting the activities of higher education, such as Brainware (Human Resources), Hardware (hardware), and Software software), or organization and its management.

One of the important steps in utilizing communication and information technology in the world of education, especially at the college level, is the development of Management Information System (MIS) of higher education. There are many reasons for the increasing efforts of universities to develop and strengthen their management information system, among others: (1) Management Information System can support operational activities and services to stakeholders, (2) Management Information System can help build effective communication to the public, about what has been done "telling the story" and able to communicate to all civitas academia openly, timely and accurately, (3) Management Information System can help to set high quality standard in learning process activity teaching, and (4) Management Information Systems can be utilized widely for accessing, managing, and utilizing large volumes of information quickly, accurately and efficiently.and (5) Management Information Systems can answer the changing demands effectively where communities demand public services meet the interests ma community, reliable and reliable, and easily accessible interactively.

The conception of Quality in Management Information Systems. In the perspectives and development of management, quality becomes the activity control (tool for detection) of successful programs, ranging from planning, organizing, implementing and evaluating (Gerst et al., 2004).

Quality is one of many concepts in the field of social science that is very difficult to define. Quality becomes a very "fashionable" subject that can "accept" different definitions, but the "core" or core of this concept is all related to client/customer satisfaction. Because of the same idea over time, the practical application of this concept differs according to the aspect in which it is applied, which proves it is a dynamic concept.

Gummesson (1990) explains to define precisely the needs of a social consensus (social consensus). However, Garvin (1980) classifies the definition of quality in five major groups: (1) Transcendent definition, this definition is subjective and personal. They 
are eternal and. This definition is related to the concept of "abstract" such as beauty and love; (2) Product definition (basic definition of product), where quality is seen as a measurable variable. The basis of measurement is the objective attribute of a product. (3) User-based definition (user-based definition), which is a quality is a means for customer satisfaction. It makes individuals and subjective; (4) Manufacturer-based definition (manufacturing-based definition). Quality is seen as conformity with specifications and specifications and (5) Value-based definition (value-based definition). This definition is related to the quality of cost and cost. Turning quality gives good value for the cost.

In general, quality can be divided as picture and size needed from fulfilling, satisfy or requirement needed from availability (punctuality); Similar definitions by Feigenbaum (1991) and Heizer and Render (2006).

Feigenbaum (1991) has the same quality and quality as expected. Meanwhile, according to Heiser and Render (2006), quality is a totality of forms and characteristics of goods or services that show the competence to satisfy the needs that appear clear or hidden.

Juran and Godfrey (1998) conception of quality in experience with fitness for use, which has the meaning of ease in producing goods and services, security and comfort in using and can meet the tastes and needs. Quality may also be referred to as the level or level of credibility that is inherent in a product sufficient to the requirements or desires of the user (ISO 9000: 2000).

In principle, quality can be defined as a "meeting" between value, compatibility, alignment or correspondence with a specification, standard, requirement, requirement or fitness fit (fit and match) of goods, products or services. Crosby (1983) defines quality as the conformity of an object, product, service or work with what is required or confirmed (conformance to requirement). While Beeby (in Arend, 2007) views quality in terms of the process in terms of the effectiveness or accuracy and efficiency of the overall factors or elements that play a role in a process.

Although in the field of education and training, quality is a relative concept (Harvey \& Green, 1993), but the quality conception can mean: (1) Quality as exceptional, focusing views and seeing quality as something special; (2) Quality as perfection or consistency, quality as perfection and consistency, by placing quality as a consistent or flawless outcome; (3) Quality as fitness for purpose, linking quality as fit for purpose, seeing quality in terms of meeting the needs, or desires of the customer; (4) Quality as value for money, quality as monetary value, which puts quality in terms of return on investment (ROI) and (5) Quality as transformation, is a classical concept, where quality as a transformation in terms of change. In the context of training, transformation refers to the enhancement of competence or the development of new knowledge (Harvey, 2004).

Referring to several definitions of the quality / quality described above, in the context of management information systems, generally the quality / quality of information systems can be interpreted as the totality of conditions of a product, service or work that has value, benefits, usefulness, conformity or compatibility with a specification, standard, requirement, requirement used to satisfy and satisfy the needs and expectations of the customer, either implicit or hidden.

At the level of the process or activity of information management, the quality / quality of the product can be the output of the information system, such as data and 
information, while for services such as services that data and information are provided by the institution, which can be accessed or used in the process of decision-making.

Furthermore, according to Ambarita (2010) process and results are two important indicators of the quality of information systems. In the process of education, quality is influenced by various factors, among others: infrastructure, raw data, information management methodology, management and administrative support, resource availability and organizational environment While quality indicators for information system results generally refer to achievement or performance achieved by institutions in a certain period of time, for example in producing information products that are used for various development activities in the organization.

In general, although the terminology of quality is a multi-dimensional concept, quality of human resources and the availability of material resources (input); 2) the quality of management and processes of data and information management (processes) and 3) the quality of results achieved (output), reliability and validity of the resulting information (International Institute for Educational Planning, 2007)

With the progress of education in Indonesia, both from the administrative or technological aspects, the Management Information System is an important factor to improve services as well as savings for the implementation of educational activities, including at higher education level. In addition, the Management Information System has now become one of the quality standards of an Education. Within the scope of universities, for example, from the 14 components of the assessment for accreditation for a university course, the management information system becomes one of the components of accreditation (BAN PT, 2003). That is why the attention to the importance of the development of management information systems for each college is a serious focus of attention to be a reliable standard of Information Systems Management.

Although the Automation/computerization of service systems and management information systems have been accomplished by educational institutions, including the university through the utilization of Management Information System, in reality, the performance of Management Information Systems is still cannot be optimized. One of the reasons that the development of Management Information System has not fully utilized the quality approach. For example, the system development policy is only done by "talkative" or following what other institutions/institutions do, regardless of internal readiness (HR, cost, time, technical design, administrative preparation, etc.). Sometimes a policy for developing information systems is managed by the management of the system that is reliable. Other factors include the overall uneven organizational structure, inadequate systems, and the essentials of the organizational structure, inadequate systems personnel, and most importantly the lack of management participation in the form of managers' participation in designing systems, controlling system development efforts and motivating all involved personnel (Ismail, 2004).

In general, quality is the description and overall characteristics of the goods or services that demonstrate its ability to satisfy the expected or implied needs. In the context of Management Information System (Information Management System) the quality of understanding includes input, process, and output of Management Information System. Input Management Information System is everything that should be available as needed for the ongoing process. Something that is meant in the form of resources and software 
and expectations as a guide for the ongoing process. The readiness of the input is necessary for the process to proceed properly. Therefore, the high quality of inputs can be measured from the level of input readiness. The higher the level of input readiness, the higher the quality of the input. The Process of Management Information System is the transformation of something into something else. Something that affects the ongoing process is called input whereas something of the result of the process is called output. In a micro-scale Management Information System (at the institutional level, the process is the decision-making process, the institutional management process, the process of program management, the teaching-learning process, and the monitoring and evaluation process, noting that the learning process has the highest importance compared to the processes others.

The process is said to be of high quality when coordinating and harmonizing and harmonizing inputs are done in harmony so that they can produce good output. Output Management Information System is an information about the performance of institutions that can be used by the management of institutions in the decision-making process. The performance of institutions can be measured by the quality, effectiveness, productivity, efficiency, innovation, quality of life and work morale work. Specifically related to quality is influenced by many stages of interconnected activities (processes) such as planning, execution, and supervision.

To be consistent and facilitate in identifying quality improvement opportunities in Management Information Systems in universities, so the quality system is always effective and efficient, the quality approach needs to be applied to the Management Information System, among others, with the following quality integration strategies: (1) Quality Approach to System; (2) Quality Approach to Information; (3) Quality Approach to Management.

Quality Approach to System. The definitive System has to be defined as the set of interacting components to achieve predetermined goals. The basic components of the system itself consist of input (input), process (process) and output (output). Characteristics of the system itself have two dimensions, the first system as "entity" or unity, that is something that has a certain order or a number of parts structurally. Second, the system as a plan, methods, tools or procedures to achieve something.

A quality approach to a system is a must for every institution, institution, company or business world. In today's industrial world where a service can be obtained from various sources, it is very important for the company to create a system that is very easy and can be remembered positively by service users/customers. Systems and procedures that facilitate the operation of an institution at least meet the 4TCM criteria as introduced by Izwar (2002) are: (1) oriented to the needs of service users/customers; (2) Open on input; (3) Exactly; (4) Integrated; (6) Fast and (7) Easy.

In order to achieve a system of 4TCM, the quality factor becomes important, because only with good quality in a system so that the system can lead, flexible/open, precise, integrated, fast and easy in anticipating the evolving needs in an institution/institution. With the quality approach than in a system can be done "systematization system". The point is that the implementation of a quality system will help achieve a synergistic effect between all elements within an organization/institution, 
including synergy of existing systems in universities (including synergy between academic and non-academic, or synergy in the field- other fields). The synergistic effect serves to direct the actions of different parts of the system which uniforms produce a greater effect than the sum of the various parts (Winardi, 1986).

The importance of a good and quality system is a concern in developing a Management Information System, very in line with the opinion of John Goodman, President of TARF. Inc., a consultancy service in America, which says: that eighty percent of the problems experienced by customers are caused by bad systems, not by bad people. Furthermore Garry Rummler (in Hohnen, 2013) argues: "You can get great people, highly trained and motivated and put them in a system and the system will win every time" (If we put a good person into a system which is bad, then the results we will get will be in accordance with the existing system ".

The quality system itself cannot be separated from system management (. Theoretically, system management is related to system theory in management or administration. It involves managerial or administrative functions or a specific program within an organization. In addition, the quality of a system is also closely related to the Philosophy System or the way of thinking that exists in a system. The way of thinking is always oriented to quality and quality improvement. Finally, a system with a quality approach in it also put forward the System Analysis as a method of problem-solving techniques within the framework of a decision-making process in an institution.

Quality Approach to Information. Conception information can be interpreted as data that has been transformed so that it has meaning and benefits for management in decision making. Vincent Gaspers (2001) says that information is data that has been processed into a meaningful form for the recipient and useful in making decisions.

Utilization of information in an organization is always associated with the function, cost, quality and value of an information. The four components of information utilization (function, cost, quality, and value) have different characteristics and dimensions, but the key factor to be considered in utilizing information is the quality control of the information function, the cost of information and the quality of the information value.

The main function of information is to increase knowledge or reduce the user's information uncertainty (management). The information conveyed to users should be data that has been processed that has a quality that can be accounted for. However, in most complex decision-making cases, information can increase the probability of certainty or reduce the various options. Often ignoring the quality control factor of the information function can be the information function that originally became the basis of the possibility to reach the selection to the decision maker (decision maker), but the information function is changed to not direct the decision maker about what to do. Whereas the function of information with the quality control approach is to reduce the diversity and uncertainty in the process of taking a decision that is good, right, right and quality (quality decisions).

In the framework of maximizing the use of information in management, Robertson, (2005) and Suter et al (2009), set out ten key principles to ensure that information management activities are effective and successful. These ten principles include: Recognise (and manage) complexity (recognizing and managing complexities within an organization); (2) Focus on adoption (focusing on adaptability); (3) Deliver tangible \& 
visible benefits (providing tangible and perceived benefits); (4) Prioritize according to business needs (prioritizing or prioritizing objectives according to the needs of organizational development); (5) Take a journey of a thousand steps (using various strategies and methods); (6) Provide strong leadership (providing strong leadership); (7) Mitigate risks (minimizing possible risks); (8) Communicate extensively (communication quality and intensity); (9) Aim to deliver a seamless user experience and (10) Choose the first project very carefully (choose the project or preliminary activity carefully).

Furthermore, regarding the cost of information realized that in various organizations the cost of data processing to meet official activities/routine. And to produce a high quality level will range from $5 \%$ to $15 \%$ of the total operating budget. The cost of operating the information system basically includes (1) Hardware cost, which is a fixed cost and will increase for higher mechanism level, (2) Cost analysis of system design and execution. This cost depends on the higher level of the mechanism, (3) the cost for the place and the environmental control factors, such as floor space cost, air conditioning, safety, etc., (4) the cost of change which includes each type of change, eg changes in the operational system of management information system tools, system updates or changes related to the software used and (5) Operating costs include human resource costs, maintenance, and repair costs, equipment supplies,

In terms of information value then the fundamental question that will arise is how big is the value of information for a particular decision problem ?. The main principle concerning it is "that information has value if that information can lead to a change in the actions taken by the decision maker." Although a data or an expert's statement may provide new knowledge, it will have no value in the context of an issue of a particular decision, as long as such additional information cannot lead to a change in attitude or action relating to the problem at hand.

Basically the value of an information is based on 10 characteristics, namely, (1) Easy to obtain, (2) Broad and complete nature, (3) Accuracy, (4) Match, (5) Timing / Accuracy, (6) Clarity, (7) ) Dexterity, (8) Can be proven, (9) No prejudices and (10) Can be measured.

The quality approach to the quality of information can be seen from the importance of the quality of information as one important factor and determine the accuracy of the decision to be taken/made. The diversity of information quality is due to biases or errors in data collection and processing. Information bias will be seen in decisions that are always missed or incorrect. For example, estimate the number of prospective graduates for each semester end.

The main issue of the quality of this information is the extent to which an organization/institution can detect the information bias that occurs. Davis (1984), reveals the causes of information bias as follows: (1) Methods of collecting and measuring wrong data, so the quality of information produced low or not quality, (2) Not follow the correct data processing procedures (quality of processing implementation data), (3) missing or untreated data (quality of data control not working properly), (4) Error in recording and checking data (process quality), (5) Incorrect or wrong history master document selecting a history document (process control quality), (6) Errors in processing procedures (eg computer program errors, device quality) and (7) deliberate errors. 
To minimize the biases of the information, of course, the quality control factor becomes very important. Steps that need to be done include: (1) Internal control/quality control to know the error. Quality control can be done both processes, implementation and all information processing activities, (2) Integrate internal and external quality control, in order to improve the quality of information to be produced, (3) Addition of "trust limit" on quality of data and (4) User instructions in processing and measurement procedures for users to assess possible errors.

Quality Approach to Management. One of the characteristics of the success of an organization, that is if the organization can provide profit for its members, ensure the continuity of the existence of its members and can provide services to those who need services/products of the organization. The success is certainly influenced by several factors. One of the factors that greatly support the success is the management system used.

In general, an organization has three levels of management. The three levels of management are (a) Administrative Management / Executive Management, (b) Middle Management / Tactical Management and (c) Management of Supervisors / Operational Management (Siagian, 2003)

Each level of management requires data and information for decision making. Therefore data and information have different values at each level of management, in accordance with the decision that will be taken by management decision maker (decision maker).

Bonita J Campbell (1982) through his book "Grammatical Man: Information Entropy, Language and Life" describes the relationship of management, information and decision making, as follows: (1) Executive management, at this level information is required to conduct prophecies, long-term forecasts, and strategic decision making. These management level activities include: (a) setting targets, (b) formulating policies, (c) organizing, (d) achieving overall effectiveness for the whole organization; (2) Middle management, at this level of management, information is used for the needs of tactical decision-making related to short-term activities and resource allocations (natural, human and financial / funding) in order to achieve the established goals. In a university context this decision usually relates to the following areas: (a) personnel issues: educative personnel, administrative staff, and students; (b) curriculum development and improvement; (c) efforts to increase the quantity and quality of graduates and (d) research and development and (3) Management oversight, at this level of management, information is required for technical decision making. Standards of technical decisions are established and the results of decisions are decisive. The making of these decisions is a process to ensure that specific tasks are implemented in an effective and efficient manner. The decision taken at this level of management is a technical decision. Examples of technical decisions at universities include: (a) Determining the distribution of guardian lecturers and guided students, (b) Approving or rejecting student courses in semester credit units, (c) Supervision of teaching and learning / academic activities of lectures, (d) Determination of lecture time, time of examination, practice etc., (e) Distribution of lecturers by subject / course name and (f) Acceptance and transmission of data or information to higher level management. 
At the operational level, the quality approach to management is focused on quality in performing management functions, ie planning, organizing, implementing and monitoring.

Planning gives criteria that must be met by an organization to achieve the goals that have been set. Quality planning becomes important because a less qualified planning then the expected results will not be optimally achieved. Therefore, the quality of plan formulation and implementation of the plan should be a concern for the management of an organization. The management oversight function has always been built with the management of subordinate activities so that the set targets can be achieved effectively and efficiently. There are three important things related to the quality approach, especially the quality of the supervision, which must be considered, namely: (1) the quality of the monitoring process should be able to measure the outputs of the system, (2) the quality of the monitoring process should be able to compare the deviations (where deviations occur) and (3) the quality of the monitoring process shall be able to correct / correct as well as the improvement of unfavorable irregularities that may interfere with the process of achieving organizational objectives.

Furthermore, there are three criteria that can be used to measure the quality of supervision performed in an organization, namely: (1) Determining the output standard, the desired results or objectives of the system, (2) Design and implementation of a sensor that collects data associated with the output measure and evaluate the output and convey the resulting information to management and (3) The workmanship of a manager or a system of mechanisms that take corrective action, information will indicate the need for necessary action. These corrective actions will result in the emergence of decisions that play a role as reintroduction into the processing system (Burns and Starter, 1987).

\section{CONCLUSION}

The quality approach in developing the Management Information System is not an end of a process, but rather as a tool where the products or services of a Management Information System meets the established standards. As a concept, the quality approach has two aspects: procedural and transformational aspects (Usman, 2006). The procedural aspect of a Management Information System is the quality produced is in conformity with the predefined standard specifications. While the transformational aspects related to quality measures lead to continuous improvement and organizational change.

With the approach of quality in Management Information System it is expected that the information system developed organized and well planned in order to provide assistance to the management/executives in an organization, the right information, fast and accurate, making it easier for the implementation of the management process effectively and efficiently at college.

\section{REFERENCES}

A Rahmat dan Widayati, Chrisina C., (2016). "Perceptual Mapping Leadership in Ethnic Regional Perspective (Studies in Six Ethnic Dominant Gorontalo)". International Journal of Economic Perspectives, 10 (2), 171-179. 
A Rahmat. (2017). "Clustering in Education”, European Research Studies Journal. XX, (3A), 311-324

Albert L. Lederer and Vijay Sethi. (2017). "Guidelines for Strategic Information Planning”. Journal of Business Strategy, 12 (6), 38 - 43

Ambarita, Biner. (2010). Manajemen dalam Kisaran Pendidikan. Bandung. Alfabeta.

Arend, Richard I. (2007). Learning To Teach: Belajar untuk Mengajar. Alih Bahasa Helly Prajitno Sutjipto, dkk. Yogjakarta. Pustaka Pelajar

Besterfield, Dale H. (2009). Quality Control. 8th Edition, Prentice Hall, New Jersey.

Burns, Tom and G.M. Stalker, (1987). The Management of Inovation, London, Taristock.

Campbell, J.B, (1982). Grammatical man: Information Entrophy, Language, and Life, New York, Simon \& Schuter).

Crosby, P.B. (1983). Don't be defensive about the Cost of Quality. Quality Progress. New York. McGraw-Hill.

Davis, Gordon B., (1984). Manajemen Information System., terjemahan oleh Bob Widyahartono, PT.Pustaka Binaman Pressindo.

Davy, K. (1998). Information strategy and the Modern Utility: Building Competitive Advantage. London: Financial Times Publishing.

Departemen Pendidikan Nasional. (2002). Manajemen Peningkatan Mutu Berbasis Sekolah. Konsep Dasar. Jakarta. Diroktorat Jenderal Pendidikan Dasar dan Menengah, Ditjen SLTP.

Departemen Pendidikan Nasional, (2003). Pedoman Akreditasi Program Magister, Badan Akreditasi Nasional, Jakarta

Eriyatno. (1999). Ilmu Sistem: Meningkatkan Mutu dan Efektivitas Manajemen. Jilid Satu. Bogor, IPB Press,

Feigenbaum, A. V. (1991). Total Quality Control. 3rd Edition. McGraw-Hill, Singapore.

Garvin, D. (1988). Managing Quality. New York. The Free Press, NY

George J. F. \& King J. L. (1991). "Examining the Computing and Centralization Debate". Communications of the ACM. 34 (7), 63-72.

Gerst, Detlef; Kranz, Almut and Möhwald, Holger. (2004). Ermittlung von Qualifizierungsbedarf im moderierten Gruppengespräch und im Einzelgespräch. Eschborn. RKW-Verlag.

Gummesson, E. (1990). Service Quality - A Holistic View. Karlstad CTF

Harvey, L. and Green, D., (1993). "Defining Quality”, Journal Assessment and evaluation in higher education, 18(1), 9-34.

Harvey, L. (2014). Analytic Quality Glossary, [online], Quality Research International, $\begin{array}{llllll}2004-13 . & \text { Diakses } & 27 & \text { Juli } & 2017 & \text { di: }\end{array}$ www.qualityresearchinternational.com/glossary/quality.htm

Heizer, Jay dan Barry Render. (2006). Operations Management (Manajemen Operasi). Jakarta. Salemba Empat.

Hohnen, Mike. (2013). Best! No Need be Cheap if You Are: Luana Mercy. eBook. It.

International Institute for Educational Planning. 2007. Supervision: A key component of a quality monitoring system. Reforming School Supervision for Quality Improvement. Module. Paris. IIEP. UNESCO.

Ismail, Mutia, (2004), Konsep Sistem Informasi, http://library.usu.ac.id/download/fe/akuntansi-mutia.pdf 
ISO 9000; 2000. (2000). Quality Management Systems - Fundamentals and Vocabulary. ISO. Geneva.

Izwar, Dian L, (2002). Tip Servis: "Easy System", Kompas, Minggu, 6 Januari 2002.

Jenner, M. G. (1995). Software Quality Management and ISO 9001 (How To Make Them Work For You). John Wiley and Sons, Inc

Juran, Joseph. M. dan Godfrey, A. Blenton. (1998). Juran Quality Handbook. 5th Edition. New York. Mc. Graw Hill

Merzuki, Siti Emalia and A. Latif, Hamrila. (2017). "Information Management (IM) for Academic Staff Advancement Programme in Higher Institutions". Journal of Technology Management \& Innovation, 4 (1), 94-104, Santiago Mayo.

Murdick, Robert G., (1980). Management Information System, New Jersey, Prentice Hall Inc.

Neyland, D. \& Surridge, C. (2002). The contest for information strategy: utilising an alternative approach to produce "Good Management Practice. In The Strategy World Congress. UK: Oxford

Senn, James A. , (1990). Information Systems in Management, Belmont, cal, 4 th edition,. Siagian, Sindang. P, (2003). Sistem Informasi Manajemen, Jakarta, PT. Bumi Aksara

Scott, George M., (1997). Principles of Management Information System, terjemahan oleh Achmad Nashir Budiman, Edisi I, PT.Raja Grafindo Persada, Jakarta,.

Suter, E., Oelke, N. D., Adair, C. E., \& Armitage, G. D. (2009). Ten Key Principles for Successful Health Systems Integration. Healthcare Quarterly .Toronto, Ont., 13.Spec No, $16-23$

Szopa, Anna dan Jalocha, Beata. (2014). Project Management in IT Type University SpinOffs. In. International Business Strategy and Enterpreunership: An Informaton Technolgy Perspective. Patricia Ordonez de Pablos (Eds.). Business Science Reference. IGI Global. Hersey PA

Usman, Husaini, (2006). Manajemen, Teori, Praktek dan Riset Pendidikan, Jakarta, PT, Bumi Aksara.

Vincent Gaspersz, (2001). Penerapan TQM pada Perguruan Tinggi di Indonesia: Suatu Upaya untuk Memenuhi Sistem Industri Modern, Jurnal Pendidikan dan Kebudayaan. No. 029, Tahun ke-7, Mei.

Winardi, (2016). Pengantar tentang teori Sistem dan Analisis Sistem, Bandung, Alumni 